\title{
Application of thermography in racehorse performance
}

\author{
by M. Soroko*, K. Howell ${ }^{* *}$ and P. Zielińska***
}

\author{
*Wrocław University of Environmental and Life Sciences, 51-161, Kożuchowska Str., Wroclaw, Poland, \\ kontakt@eqma.pl \\ ${ }^{* *}$ Royal Free Hospital, NW3 2QG Pond Str., London, UK, k.howell@ucl.ac.uk \\ *** Wrocław University of Environmental and Life Sciences, 50-366, pl. Grunwaldzki Str., Wrocław, Poland, \\ paulina.zielinska@up.wroc.pl
}

\begin{abstract}
Thermography has found a broad range of applications in veterinary medicine and racing performance. The usefulness of thermography in veterinary medicine has been proved in detecting pathological conditions associated with inflammatory, vascular or neurological pathological disorders. The main advantage of thermography is the detection of subclinical signs of inflammation before the onset of clinical signs of pathology, providing great value in veterinary medicine diagnosis. Thermographic diagnosis is useful in monitoring changes of horse surface temperature resulting from exercise, allowing evaluation of the work of individual parts of the body in racing performance. Regular assessment of body surface temperature allows the detection of training overloads and identification of pathological conditions of the musculoskeletal system during the racing training cycle.
\end{abstract}

\section{Introduction}

Most racehorse injuries are associated with the physical demands of the musculoskeletal system in response to training [1], and they can also be linked to the type of training and the skills of the rider [2]. The detection and monitoring of physiological responses to training overloads is particularly important for racehorses put under extreme physical demands. In the study presented by Jeffcott et al. [2], out of 163 thoroughbred racehorses $53 \%$ suffered from lameness, which was the main cause of elimination of the horses from sport performance. A more recent study involving Thoroughbred racehorses recorded an $81 \%$ incidence of lameness [3]. Thermography has been confirmed as a valuable aid in regular assessment of racehorse training [5-7].

\section{Application of thermography in injury diagnosis}

Thermography can indicate areas of inflammation that could account for a decreased level of racing performance [5]. Regular thermographic examination has been widely used in veterinary medicine in the evaluation of soft tissue injury and superficial bone lesions as an imaging modality complementary to ultrasonographic and radiographic examinations [8-12]. Thermography has assisted in the diagnosis of a variety of limb injuries including tendonitis, inflammation of the stifle, carpal, tarsal, fetlock joints (fig. 1), and bucked shins (fig. 2) [8,13-16]. It can detect abnormalities associated with hoof like: navicular syndrome, corns, laminitis, sole abscesses (fig. 3) and other hoof related structural problems [8, 17]. For back abnormalities it has been applied in neuromuscular disease of the thoracolumbar region, muscular and spinous process inflammation of the thoracic vertebrae (fig. 4), subluxation of the third lumbar vertebrae, supraspinal and interspinal ligament inflammation and intervertebral inflammation of the thoracolumbar vertebrae $[8,11,17,18]$.

Thermography has also been used as a first examination tool for the detection of subclinical inflammation, before the onset of clinical signs of injury only later clinically confirmed by radiography and ultrasonography [10,19]. It diagnosed subclinical signs of tendonitis and joint arthritis prior to the appearance of clinical signs of inflammation [13,20, 21]. In the study presented by Turner et al. [5] out of 127 specific limb problems in racehorses, 120 abnormalities were predicted 2 weeks before they became evident clinically. Other studies also report possible detection of subclinical inflammation in racehorses [14,15]. Soroko et al. [19] found that temperature differences of $1.25^{\circ} \mathrm{C}$ between the right and left distal parts of limbs could indicate subclinical inflammation of the superficial digital flexor tendon and bucked shins in racehorses. Turner [14] found local temperatures over the dorsal $3^{\text {rd }}$ metacarpal bone were $1^{\circ} \mathrm{C}$ to $2^{\circ} \mathrm{C}$ higher compared to the surrounding areas in the early stages of bucked shins. Thermography can protect the horse from injury by detecting signs of inflammation in the distal parts of the limbs before any clinical evidence such as lameness is present $[14,21]$. 


\section{Application of thermography in racing performance}

In racing performance, thermography is useful in monitoring changes of horse surface temperature resulting from regular intensive training, allowing evaluation of the function of individual parts of the body [22]. Assessment of body surface temperature indicates areas of the body that could account for a decreased level of racing performance [5]. Regular thermographic examination found abnormalities of forelimbs associated with strains and overloads in racehorses $[6,23]$. This confirms that most horses are more likely to develop injury associated with the forelimb, than the hindlimb [24]. In another study it was found that the temperature of the back and the distal parts of the forelimbs at rest was increased by long-term training $[7,25]$. Ten months of regular thermographic examination identified thirteen body regions of interest (ROIs) at both carpal joints, the 3rd metacarpal bones, the left fetlock joint, the left front short pastern bone, the left tarsus joint, and the caudal part of the thoracic vertebrae to be recommended for monitoring the impact of training [6]. Identifying the key thermographic diagnostic areas should facilitate the detection of pathological conditions during the training cycle.

Thermography can play a role in equine rehabilitation for the detection of upper limb muscle strain, muscle inflammation, croup and caudal thigh myopathy $[26,27]$. It provides objective data that can indicate the area at which to concentrate further diagnostic testing or apply therapeutic ultrasound, massage or other treatment [26]. In the study presented by von Schweinitz [28] thermography assisted in monitoring the effectiveness of acupuncture therapy in a case of neuromuscular disease. Both Waldsmith and Oltman [29] and Yarnell et al. [30] have highlighted the potential of thermography for monitoring rehabilitation, but more published evidence is required to demonstrate its true utility.

Thermography has also been used to aid detection of illegal performance-enhancing procedures during equestrian competition [31]. A serious limitation in this application, however, is a lack of specificity: increase in heat in the digits may not be due to a specific drug, and could simply relate to being in work at the time of examination. The FEI currently approves thermography as a method for detection of hypersensitisation, but the guidelines for use are somewhat non-specific, which has probably limited the uptake of the technique for this purpose [32].

\section{Summary}

Thermography is becoming increasingly popular as an aid to assist the diagnosis of musculoskeletal pathology in racehorses. It helps veterinarians to diagnose the exact site of injury and follow the response to treatment. Thermography detects training overloads and muscle strains which can lead to injury, allowing the trainer to make decisions about the horse's training programme and management. Increasing camera performance at reduced cost is making thermography more accessible than ever before, allowing more horses and trainers to benefit from this noninvasive imaging modality.

\section{REFERENCES}

[1] Rossdale P.D., Hopes R., Wingfield-Digby N.J., Offord K., Epidemiological study of wastage among racehorses 1982 and 1983, Veterinary Record - Vol. 116, no 3 (1985), pp. 66-69, 1985.

[2] Schöllhorn W.I., Peham C., Licka T., Scheidl M., A pattern recognition approach for the quantification of the horse and rider interactions, Veterinary Journal - Vol. 36, (2006), pp. 400-405, 2006.

[3] Jeffcott L.B., Rossdale P.D., Freestone J., Frank C.J., Towers-Clark P.F., An assessment of wastage in Thoroughbred racing from conception to 4 years of age, Equine Veterinary Journal - Vol. 14, no 3 (1982), pp. 185-198, 1982.

[4] Williams R.B., Harkins L.S., Hammond C.J., Wood J.L., Racehorses injuries, clinical problems and fatalities recorded on British racecourses from flat racing and national hunt racing during 1996, 1997 and 1998, Equine Veterinary Journal - Vol. 33, no 5 (2001), pp. 478-486, 2001.

[5] Turner T.A., Pansch J., Wilson J.H., Thermographic assessment of racing thoroughbreds, Proceedings of the American Association of Equine Practitioners. - Vol. 47, (2001), pp. 344-346, 2001.

[6] Soroko M., Dudek, K., Howell, K., Jodkowska, E., Henklewski R., Thermographic evaluation of racehorse performance, Journal of Equine Veterinary Science - Vol. 34 no 9, (2014), pp.1076-1083, 2014.

[7] Soroko M., Jodkowska E., Dudek K., Thermography diagnosis in monitoring annual racehorses' training cycle, Medycyna Weterynaryjna - Vol. 71, no 01 (2015), pp. 52-58, 2015.

[8] Purohit R.C., McCoy M.D., Thermography in the diagnosis of inflammatory processes in the horse, American Journal Veterinary Research - Vol. 41, no 8 (1980), pp. 1167-1174, 1980.

[9] Turner T.A., Fessler J.F., Lamp M., Pearce J.A., Geddes L.A., Thermographic evaluation of horses with podotrochlosis, American Journal Veterinary Research - Vol. 44, no 4 (1983), pp.535-539, 1983.

[10] Turner T.A., Diagnostic thermography, Veterinary Clinics of North America: Equine Practice - Vol. 17, no 1 (2001), pp. 95-113, 2001.

[11] Fonseca B.P.A., Alves A.L.G., Nicoletti J.L.M., Thomassian A., Hussini C.A., Mikaik S., Thermography and ultrasonography in back pain diagnosis of equine athletes, Journal of Equine Veterinary Science - Vol. 26, no 11, (2006) pp. 507-516, 2006.

[12] Purohit R.C., "Use of thermography in veterinary medicine". Rehabilitation Medicine and Thermography, pp. 135-147, Impress Publication, Morrisville, 2008. 
[13] Bowman K.F., Purohit R.C., Ganjam V.K., Pechman Jr R.D., Vaughan J.T., Thermographic evaluation of corticosteroid efficacy in amphotericin B - induced arthiritis in ponies, American Journal of Veterinary Research - Vol. 44, no 1 (1983), pp. 51-56, 1983.

[14] Turner T.A., Thermography as an aid to the clinical lameness evaluation, Veterinary Clinics of North America: Equine Practice - Vol. 7, no 2 (1991), pp. 311-338, 1991.

[15] Soroko M., Analyses of superficial temperature distribution of lower part of the limbs in young racing horses, Measurement, Automation and Monitoring - Vol. 57, no 10 (2011), pp.1157-1160, 2011.

[16] Purohit R.C., Pascoe D.D. and Turner T.A., "Use of infrared imaging in veterinary medicine". The Biomedical Engineering Handbook, 3rd edn. pp 35, 1-8, CRC Press Taylor and Francis Publication, Boca Raton, 2006.

[17] Turner T.A., Rantanen N.W., Hauser M.L. "Alternate methods of soft tissue imaging", 1st Proceedings Dubai International Equine Symposium, pp 165-176, 1996.

[18] von Schweinitz D.G., Thermographic diagnosis in equine back pain, Veterinary Clinics of North America Equine Practice 15, (1999), pp.161-177, 1999.

[19] Soroko, M., Henklewski, R., Filipowski, H., Jodkowska, E. The effectiveness of thermographic analysis in equine orthopaedics, Journal of Equine Veterinary Science - Vol. 33 (2013), pp. 760-762, 2013.

[20] Stromberg B., The use of thermography in equine orthopaedics, Journal of the American Veterinary Radiology - Vol. 15 no 1 (1974), pp.94 - 97, 1974.

[21] Vaden M.F., Purohit R.C, McCoy D., Vaughan J.T., Thermography: a technique for subclinical diagnosis of osteoarthritis, American Journal of Veterinary Research - Vol. 41 no 8 (1980), pp. 1175-1180, 1980.

[22] Jodkowska E., Temperatura powierzchni ciała jako kryterium predyspozycji wysiłkowych konia, Zeszyty Naukowe Akademii Rolniczej, 511, 2005.

[23] Soroko M., Thermographic diagnosis of sport horses' limbs, Biomedical Engineering - Vol 17 no. 2, (2011), pp. 104-109, 2011.

[24] Peloso J.G., Mundy G.D., Cohen N.D., Prevalence of, and factors associated with, musculoskeletal racing injuries of Thoroughbreds, The Journal of the American Medical Association - Vol. 204 no 4, (1994), pp.620626, 1994.

[25] Soroko M., Jodkowska E., Zabłocka M., The use of thermography to evaluate back musculoskeletal responses of young racehorses to training, Thermology International - Vol. 22, no 3 (2012), pp. 152-156, 2012.

[26] Turner T.A., Thermography as an aid in the localization of upper hindlimb lameness. Pferdeheilkunde - Vol.12, (1996), pp. 632-634, 1996.

[27] Turner T.A. The use of thermography in lameness evaluation, In Proceeding of the American Association of Equine Practitioners - Vol. 44, (1998), pp. 224-226, 1998.

[28] von Schweinitz D.G. Thermographic evidence for the effectiveness of acupuncture in equine neuromuscular disease. Acupuncture in Medicine - Vol. 16, (1998), pp. 14-17, 1998.

[29] Waldsmith and Oltman (1994) Waldsmith J.K., Oltman J.I., Thermography: subclinical inflammation, diagnosis, rehabilitation, and athletic evaluation, Journal Equine Veterinary Science - Vol. 14, no 1 (1994), pp. 8-10, 1994.

[30] Yarnell, K., Fleming, J., Stratton, T.D., Brassington, R., Monitoring changes in skin temperature associated with exercise in horses on a water treadmill by use of infrared thermography, Journal of Thermal Biology - Vol. 45 , (2014), pp. 110-116, 2014.

[31] Van Hoogmoed L.M., Snyder J.R., Use of infrared thermography to detect injections and palmar digital neurectomy in horses, Veterinary Journal - Vol. 164, no 2 (2002), pp. 129-141, 2002.

[32] International Equestrian Federation (2016). 2016 Veterinary Regulations 13th Edition. Available from: <http://www.fei.org/sites/default/files/VRs\%202016\%20-\%20FINAL\%20-\%20marked\%20up.pdf>[24 March 2016]. 
10.21611/qirt.2016.122

Figures:

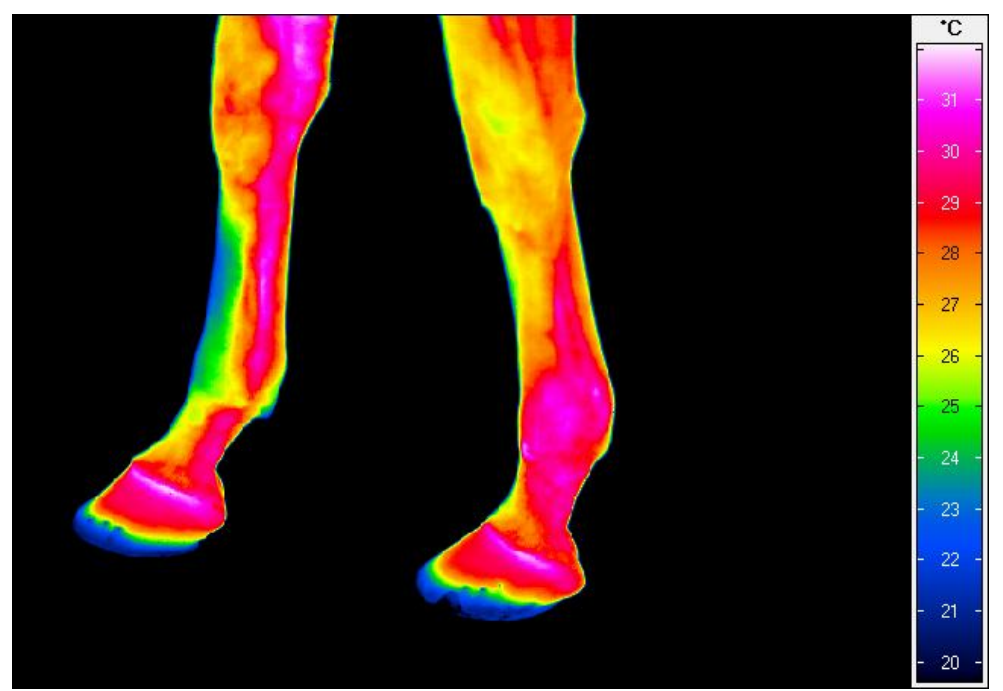

Fig. 1. Thermogram of the left lateral and right medial aspects of the forelimbs. Inflammation of the left fetlock joint.

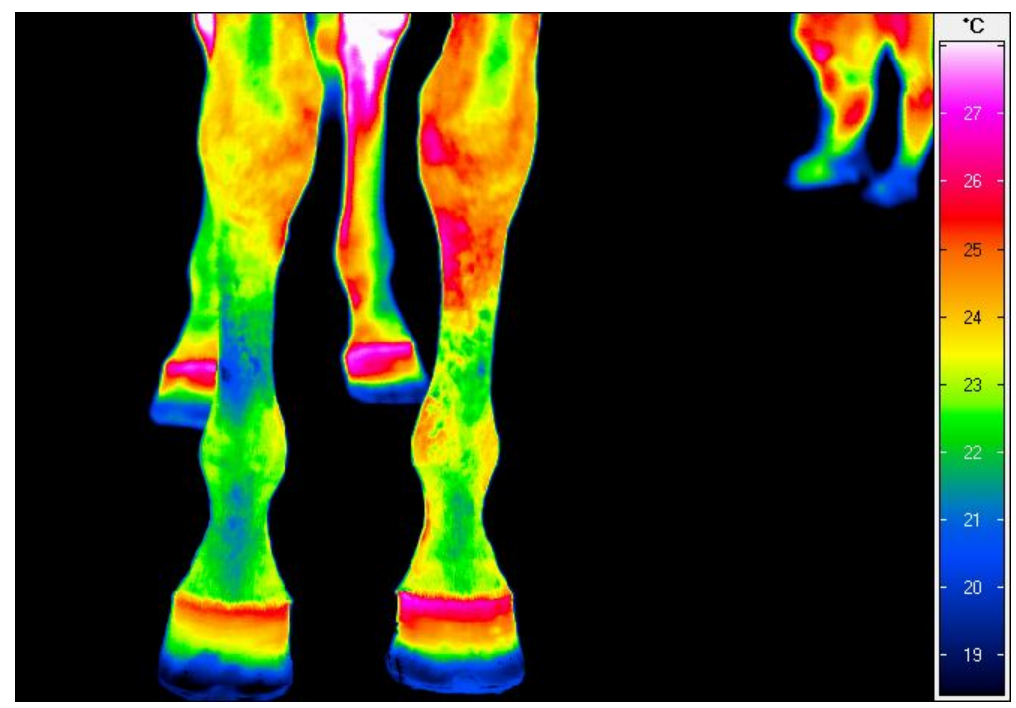

Fig. 2. Thermogram of dorsal aspect of distal part of forelimbs. Bucked shins of the left 3rd metacarpal bone. 


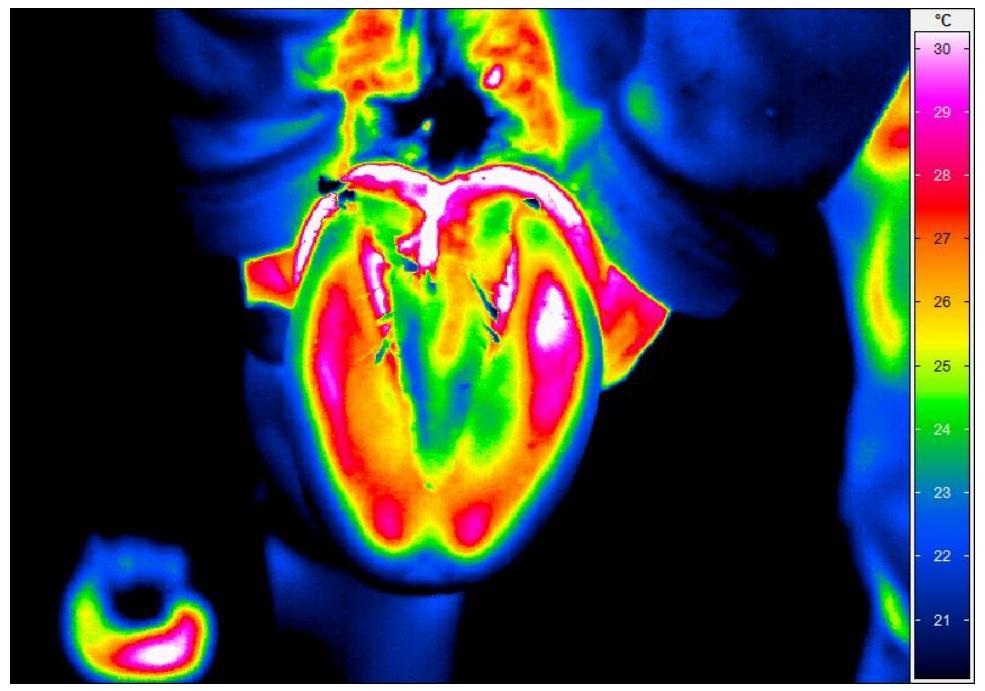

Fig. 3. Thermogram of the right hoof sole. Abscess at the lateral (right) side of the hoof sole.

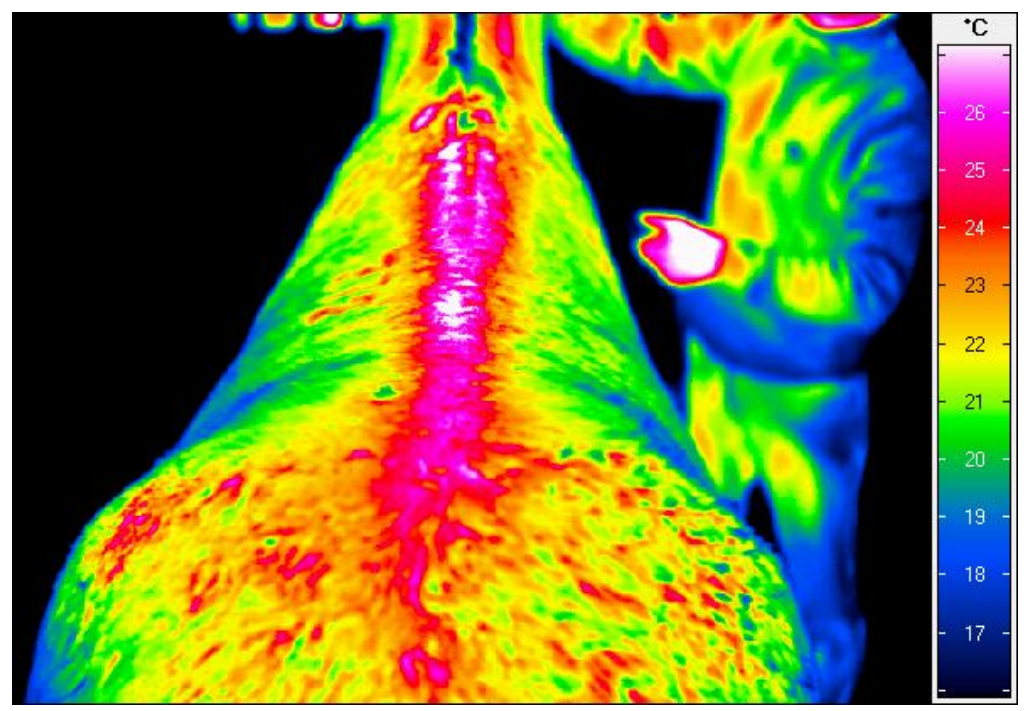

Fig. 4. Thermogram of the dorsal aspect of the back. Spinous process inflammation of the thoracic vertebrae. 